\title{
Luticola rojkoviensis sp. nov. (Bacillariophyta), a new terrestrial diatom from Central Slovakia
}

\author{
Alica Hindákoví ${ }^{1 *} \&$ Teresa NogA ${ }^{2}$
}

\author{
${ }^{I}$ Institute of Botany, Plant Science and Biodiversity Centre, Slovak Academy of Sciences, Dúbravská cesta 9, \\ SK-84523 Bratislava, Slovakia, *Corresponding authore-mail: alica.hindakova@savba.sk \\ ${ }^{2}$ Department of Soil Studies, Environmental Chemistry and Hydrology, Faculty of Biology and Agriculture, \\ University of Rzeszów, ul. Zelwerowicza 8B, PL-35-601 Rzeszów, Poland
}

\begin{abstract}
Sampling of fungi in a grassland on a hill in Rojkov, Central Slovakia, revealed a new species of Luticola (Diadesmidaceae). Its terrestrial populations were found close to the basis of the fertile part of the geoglossoid fungi (Geoglossaceae) that were overgrown with filamentous cyanobacteria of the orders Oscillatoriales and Synechococcales. Luticola rojkoviensis sp. nov. is characterized by the valve outline and the structure of the external valve face: valves are weakly dorsiventrally asymmetrical, rhombic-lanceolate in larger cells to rhombic-elliptic and tri-undulate in smaller cells, with shortly protracted and broadly rounded valve apices. Valve face is minimally concave, as the axial area is lowered and the area around distal raphe elevated. The surface of the valve is mostly uneven due to many depressions, so the external shape of the areolae and the impression of irregular longitudinal rows depend on the extent of these valve ornamentations. Proximal raphe endings are unilaterally slightly deflected, expanded into small central pores. The shape of both the proximal and the distal raphe fissures is slightly asymmetrical. The morphological characteristics of Luticola rojkoviensis sp. nov. are remarkably similar to those of $L$. hustedtii Levkov, Metzeltin et A.Pavlov, L. ectorii Levkov, Metzeltin et A.Pavlov and $L$. acidoclinata Lange-Bertalot. The association of Luticola rojkoviensis sp. nov. with geoglossoid fungi and epiphytic cyanobacteria is discussed.
\end{abstract}

Key words: terrestrial diatoms, Luticola, new species, Central Slovakia

\section{INTRODUCTION}

Since the establishment of new genus Luticola D.G. Mann in 1990 with the type species L. mutica (Kütz.) D.G.Mann, the number of taxa has grown enormously, from 30 in 1990 (Round et al. 1990) to 239 taxa in 2020 according to Algaebase (GUIRY \& GUIRY 2020). The increase of new Luticola species reflects intensive studies, mostly based on materials from extreme regions including Antarctica (VAN De ViJver et al. 2006; Kopaloví et al. 2009, 2011; ZidArova et al. 2014; KoHLER et al. 2015; KocioleK et al. 2017), South America (WetZel et al. 2010; Straube et al. 2017), islands in the southern Indian Ocean (Chattová et al. 2017), Madagascar (BĄK et al. 2019) and Asia (GLUSHCHENKo \& KULIKOvSKYI 2015; GLuSHCHENKo et al. 2017) and also on historical diatomological collections. The number of endemic species from these extreme regions is high, and many of them have been found in soil and subaerial habitats (KocioleK et al. 2017).

Representatives of the genus Luticola occurring in Europe have been summarized in the monograph on
Luticola and Luticolopsis in the edition „Diatoms of Europe“, 24 of which have been identified as new taxa (Levkov et al. 2013). The authors presented a synopsis and revision of approximately 200 taxa. For practical reasons, they assigned these taxa to 17 artificial groups (group A - group Q) exclusively on the basis of eight morphological characteristics, without a consideration of their systematic and phylogenetic relationships, geographical distribution and ecological requirements.

Later records from Europe come from studies of microecosystems and are important for knowledge of the local algal microflora, e.g. findings of $L$. frequentissima Levkov, Metzeltin et A.Pavlov from alkaline and near neutral waters, soils, aerophytic places in the Bieszczady National Park and the Magura National Park in Southern Poland (Noga et al. 2017). LevKov et al. (2017) provided knowledge about the halomorphic soil microflora in Gladno Pole, an extreme environment in Macedonia. Four taxa were described as new halophytic diatoms.

Many modern molecular studies have been carried out on diatoms (e.g. Soufrreau et al. 2013; Pinseel et al. 2016; Ashworth et al. 2017; OGURA et al. 2018), 
nevertheless the description of new taxa remains so far based on detailed morphological characteristics of frustules. Some molecular studies necessitate reevalution of the concept of the family Diadesmidaceae sensu Round et al. (1990) and GUIRY \& GUIRY (2020). In the phylogenetic trees of ANDrEEva et al. (2016) and NAKov et al. (2018) the genera Luticola, Diadesmis and Humidophila (with species mostly reclassified from the genus Diadesmis) are not closely related and most probably have a different evolutionary history.

In the last decade, floristic observations in the Rojkov area (Vel'ká Fatra mountains, C Slovakia) were carried out in connection with initiatives to protect the travertine flora, incl. the microflora of the Nature Reserve (NR) Rojkovské rašelinisko and of the mineral springs of the NR Močiar, a fen located near the village Stankovany (ToPERCER \& BERNÁTOvá 2013; Hindáková \& HiNDÁK 2015).

In the present study we describe a new terrestrial Luticola species from grassland on the hill in the village of Rojkov. In winter, this hill is used for skiing, therefore grassland is maintained by mowing or grazing by sheep throughout the year. The populations of L. rojkoviensis sp. nov. were present close to the basis of the fertile part of geoglossoid fungi (Geoglossaceae) which were overgrown by filamentous cyanobacteria. The ultrastructure of the new Luticola species reveals a morphological similarity to species that have been placed in group , $\mathrm{N}$ - species with rhombic to rhombic-lanceolate outline and/or narrowly capitate/rostrate apices“" (e.g. L. hustedtii) or in the group „D - small species with rhombic-lanceolate valve shape" (e.g. to L. ectorii) according to LEVKOV et al. (2013). The groups are not strictly defined in this monograph, in the case of overlapping morphological features it is possible to consider several of them.

Luticola rojkoviensis, a new terrestrial pennate diatom, is the result of our interest in associations of geoglossoid fungi (earth tongues) and epiphytic filamentous cyanobacteria of the orders Oscillatoriales and Synechococcales.

\section{MATERIAL AND METHODS}

Field sampling. The samples studied were originally collected as mycological material from a grassland of the hill in the village of Rojkov, Vel'ká Fatra Mts (GPS coordinates: $\left.49^{\circ} 08^{\prime} 52.8^{\prime \prime} \mathrm{N} 19^{\circ} 09^{\prime} 15.1^{\prime \prime} \mathrm{E}\right)$. The rock environment is formed by the Mráznica Formation (grey marly limestones and marly shales) which is covered by diluvial Quaternary sediments (loamy-stony talus sediments) (PoLÁK et al. 1997). The sampling point is supplied by groundwater from the slope, from the south (MALÍK et al. 2006).

Our observations have revealed that Trichoglossum octopartitum, a representative of geoglossoid fungi known as earth tongues, serve as a substrate for filamentous cyanobacteria and various soil algae. In the field, 3-4 cm large fertile above ground parts of fungi were collected in November 2018, May and October 2019. These fungi are rare in Slovakia, therefore only some pieces were detached from the soil and stored in plastic containers. In the laboratory, the black fertile parts of fungi were placed in Petri dishes containing a thin layer of Bold's Basal medium (BBM) agar and maintained as a subcultures (Zimmerkulturen). In some Petri dishes with material from 2019, brown colonies of diatoms were visible in a few days on the lowest part of the fungi. Cells of Luticola species were inoculated in new Petri dishes with BBM-agar to prevent overgrowth by other cyanobacteria and algae. They were kept as natural populations in the culture room at a temperature $21{ }^{\circ} \mathrm{C}$, illumination $20 \mathrm{mmol} \cdot \mathrm{m}^{-2} \cdot \mathrm{s}^{-1}$ for a maximum of several weeks. For documentation purposes, part of the material was fixed in alcohol. To prepare permanent slides, the material was first cleaned with distilled water, then boiled in $30 \% \mathrm{H}_{2} \mathrm{O}_{2}$ for 2 hours and washed three times with distilled water. Small amount of sample was placed on the cover glass, left to dry and mounted onto glass slides with Naphrax diatom mountant. Light microscope observations were carried out with a Leitz Diaplan microscope, and micrographs were taken with a digital microscope camera Zeiss AxioCam ICc3. For SEM observations, the cleaned material (boiled with $30 \% \mathrm{H}_{2} \mathrm{O}_{2}$ and thoroughly washed five times with distilled water) was placed on a Whatman Nucleopore $5 \mu \mathrm{m}$ mesh polycarbone membrane on aluminium stubs and coated with $20 \mathrm{~nm}$ gold. Ultrastructure of diatoms was examined under a Hitachi SU 8010 scanning electron microscope at the University of Rzeszów, Poland. The studied material (permanent slides and cleaned fixed materials) is deposited at the CBRB Institute of Botany, Bratislava, Slovakia, and the SEM material at the University of Rzeszów, Poland.

\section{ReSULTS}

Luticola rojkoviensis Hindáková et Noga sp. nov. (Figs 1-30: LM, Figs 31-46: SEM)

Description: Cells solitary, naviculoid, weakly asymmetrical with respect to the apical axis, containing a single lobed chloroplast, $\mathrm{H}$-shaped in girdle view. One central pyrenoid, oval in valve view, lying near the girdle on the secondary side of cell. Frustules rectangular in girdle view (Fig. 21, 38). Valve mantle with single row of round areolae, each girdle band with two rows of round poroids (Fig. 38).

Valves rhombic-lanceolate to rhombic-elliptic with weakly tri-undulate margins in smaller cells (Figs 9, 11). Valve apices slightly protracted to broadly rounded, bent to the secondary side of valves. Valve length $11.7-32 \mu \mathrm{m}$, valve width $6-9 \mu \mathrm{m}$ (the valve ratio by smaller valves 2.2:1, by larger valves 3.6:1). Valve face flat or uneven due to numerous shallow depressions, not penetrating the valve. Depressions ranging from indistinct (or missing, Fig. 31) to markedly formed throughout the valve face (Figs 34-36, 39-44). Axial area narrow, linear, slightly expanded near central area and very slightly lowered (Fig. 36). Central area wide, weakly asymmetrical, wedge-shaped, on both sides bordered by 3-5 isolated round areolae. Stigma single, round, distinct, in asymmetrical position in the central area - near the valve margin of the secondary side, isolated - never associated with a stria. The internal opening of the stigma covered with a tongue-like structure (Fig. 37). 
Striae uniseriate, distinctly punctate in LM, radiate throughout, on the secondary valve side mostly interrupted in the first fifth of the cell length (Voigt discontinuity, in small valves causes change in direction of striae to divergent, arrows in Fig. 37). Striae in smaller specimens (21)-22-24-(25) in $10 \mu \mathrm{m}$, in larger specimens (18)-19-21 in $10 \mu \mathrm{m}$, composed of 2-7 areolae arranged at an irregular distance giving the impression of irregular longitudinal rows in LM (e.g. Fig. 22). The external opening of areolae round to transversely elongated, even variable in one stria, recessed or not recessed in the valve depressions. Internally areolae occluded by hymenes which tend to merge into strips these connections remain narrower and the entire strip is strangled (Figs 37, 45, 46).

Raphe branches straight. Proximal raphe endings unilaterally slightly deflected to opposite side to stigma (primary side of the valve), slightly asymmetrical and expanded into small central pores. Distal raphe endings unilaterally hooked to the stigma side (secondary side of the valve), first deflected towards the primary side of the valve, then bent to the secondary side of the valve, but remaining positioned on the primary side of the valve according to the apical axis (e.g. Fig. 42), in the shape of a question mark up to a bayonet-shape in larger cells. The proximal raphe fissures differ negligibly in shape from each other (Figs 40, 44), as do the distal raphe fissures (Fig. 41).
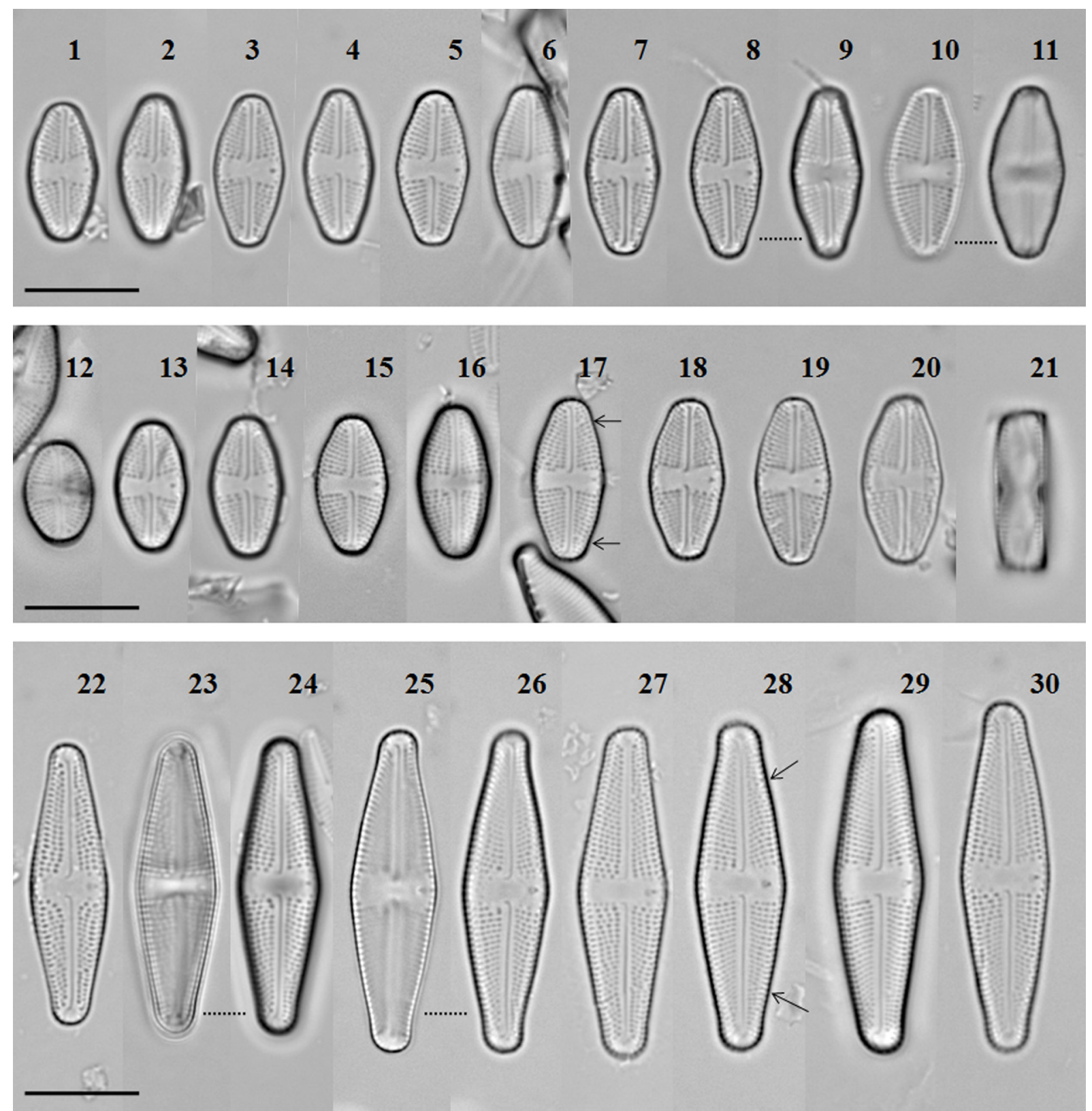

Figs 1-30. Luticola rojkoviensis sp. nov. LM: (1-20) small weakly asymmetric valves in valve view, $(9,11)$ focus on triundulate valves, (17) the arrows point to Voigt discontinuity; (21) small frustule rectangular in girdle view; (22-30) large valves, (29) designated holotype, (28) arrows point to Voigt discontinuity. Scale bar $10 \mu \mathrm{m}$. 
The part of valve apex with distal raphe endings very slightly elevated (Figs 36, 43, 44). Distal fissures terminating on the valve mantle near the edge. Internal raphe slits simple and straight, proximal raphe fissures slightly deflected towards stigma (Fig. 46), the distal raphe fissures also bent to the stigma side and ending in rather inconspicuous helictoglossae (Figs 37, 45). Marginal channel located on the valve face-mantle, indistinct, occluded with hymen (Figs 37, 45, 46).

Holotype (designated here): Slide AH2019-755 in Coll. Herbarium of A. Hindáková, at the CBRB, Slovakia. Holotype specimen is represented by Fig. 29.

Type locality: grassland on a hill in the village of Rojkov, GPS coordinates: $49^{\circ} 08^{\prime} 52.8^{\prime \prime} \mathrm{N}, 19^{\circ} 09^{\prime} 15.1^{\prime \prime E}$, Vel'ká Fatra mountains, Central Slovakia. Leg. V. Kučera.

Etymology: The specific epithet refers to the type locality Rojkov.

Distribution: Species so far found only in the type locality.

Luticola rojkoviensis sp. nov. resembles some species which are included in groups $\mathrm{N}$ and $\mathrm{D}$ sensu LEVKOV et al. (2013). Its main morphological features and those of similar species, together with their habitat preferences are summarized in Table S1. In similar taxa, we used only the original descriptions to avoid some inaccuracies in their characteristics included in the monograph (e.g. cell dimensions, expression of the shape description), which are related with the fact that the source material was obtained from different sites, not from a type locality. Information given in Table S1 together with the information in the Luticola and Luticolopsis monograph published by LEVKOV et al. (2013) is the subject of our discussion.

\section{DisCUSSION}

Luticola rojkoviensis sp. nov. is morphologically remarkably similar to L. hustedtii Levkov, Metzeltin et A.Pavlov, a representative of the group $\mathrm{N}$ sensu LEVKOV et al. (2013). What separates these species is the valve outline - valves are more rhombic, distinctly expanded in middle, minimally asymmetric and the valve ends are slightly protracted to subcapitate in the latter. Furthermore, in the shape of proximal raphe slits, they are slightly deflected in a new species and perpendicularly deflected in the latter. Distal raphe fissures in Luticola rojkoviensis sp. nov. are bayonet-shaped in large frustules (this shape is rather typical for representatives of the genus Pinnularia), not question mark-shaped as in L. hustedtii. The ornamentation of the valve face of both taxa is almost identical.

L. ectorii Levkov, Metzeltin et A. Pavlov, a representative of the group D sensu LEVKOV et al. (2013), also fits into this pattern. It resembles the new Luticola with respect to slightly asymmetric valves with undulate margins and the ornamentation of valve face. Both taxa can be differentiated from each other mainly by the valve outline (valves of $L$. ectorii are more rhombic and expanded in the middle, somewhat resembling the valve outline of L. rhombica), the shape of the central area and the shape of both raphe fissures (the same differences as for L. hustedtii vs L. rojkoviensis sp. nov., see above).

L. rojkoviensis sp. nov. resembles $L$. acidoclinata Lange-Bertalot in some respects. In this case, it is necessary to proceed to the evaluation of similarities through the original description of the type material based only on LM photographs (LANGE-BERTALOT \& Metzeltin 1996). The valve-outline is similar, although the undulation of margins is in the opposite cell size: in the smaller frustules of L. rojkoviensis sp. nov. vs in all frustules except small ones in L. acidoclinata. Apart from this, L. rojkoviensis sp. nov. might be confused with smaller valves of $L$. acidoclinata, but the shape of large valves of new Luticola is more lanceolate and rather resembles large valves of $L$. fuhrmanii. Based on the German original diagnosis of L. acidoclinata, both taxa also differ in the shape of stigma (which appears as a dash internally in L. acidoclinata) and in the shape of proximal raphe fissures (which are strongly hooked "stark abgekrümmt" in L. acidoclinata, but only slightly deflected in L. rojkoviensis sp. nov.). The ultrastructure of many populations determined as L. acidoclinata from different parts of Europe and USA (LEVKOV et al. 2013, 2017) show a clear difference in the shape of proximal raphe slits, which are doubly curved or clearly deflected (perpendicularly). Additionaly, differences can be found in the shape of distal raphe endings - in the form of question mark in L. acidoclinata, whereas the distal raphe endings in L. rojkoviensis sp. nov. reach the shape of bayonet. However, it is noted that we are not dealing with a comparison of the ultrastructure of type material.

A comparison of L. rojkoviensis sp. nov. with other species listed in our table (Table $\mathrm{S} 1$ ) is presented below, with emphasis on some morphological characteristics.

\section{Cell symmetry}

The genus Luticola belongs to the pennate diatoms and to the category of symmetric biraphid diatoms (SPAULDING \& EDLUND 2008). A new suborder Neidiineae of the order Naviculales was established by D.G. Mann, which contained the new family Diadesmidaceae D.G.Mann with two representatives Diadesmis F.T.Kützing and Luticola D.G. Mann gen. nov. (Round et al. 1990). Both genera appeared to be closely related, but could be easily separated by different structure of raphe, pores and stigma. The original description of Luticola gen. nov. lacks any remark on the asymmetry of valves. The weakly asymmetry of cells (dorsiventral) was mentioned in the extended description of this genus and is supported by LM and SEM analyses of some Luticola taxa included in the monograph (LEVKOV et al. 2013).

The valves characterised by subtle asymmetrical differences in the valve outline have recently been the subject of geometric morphometric studies using decomposition 


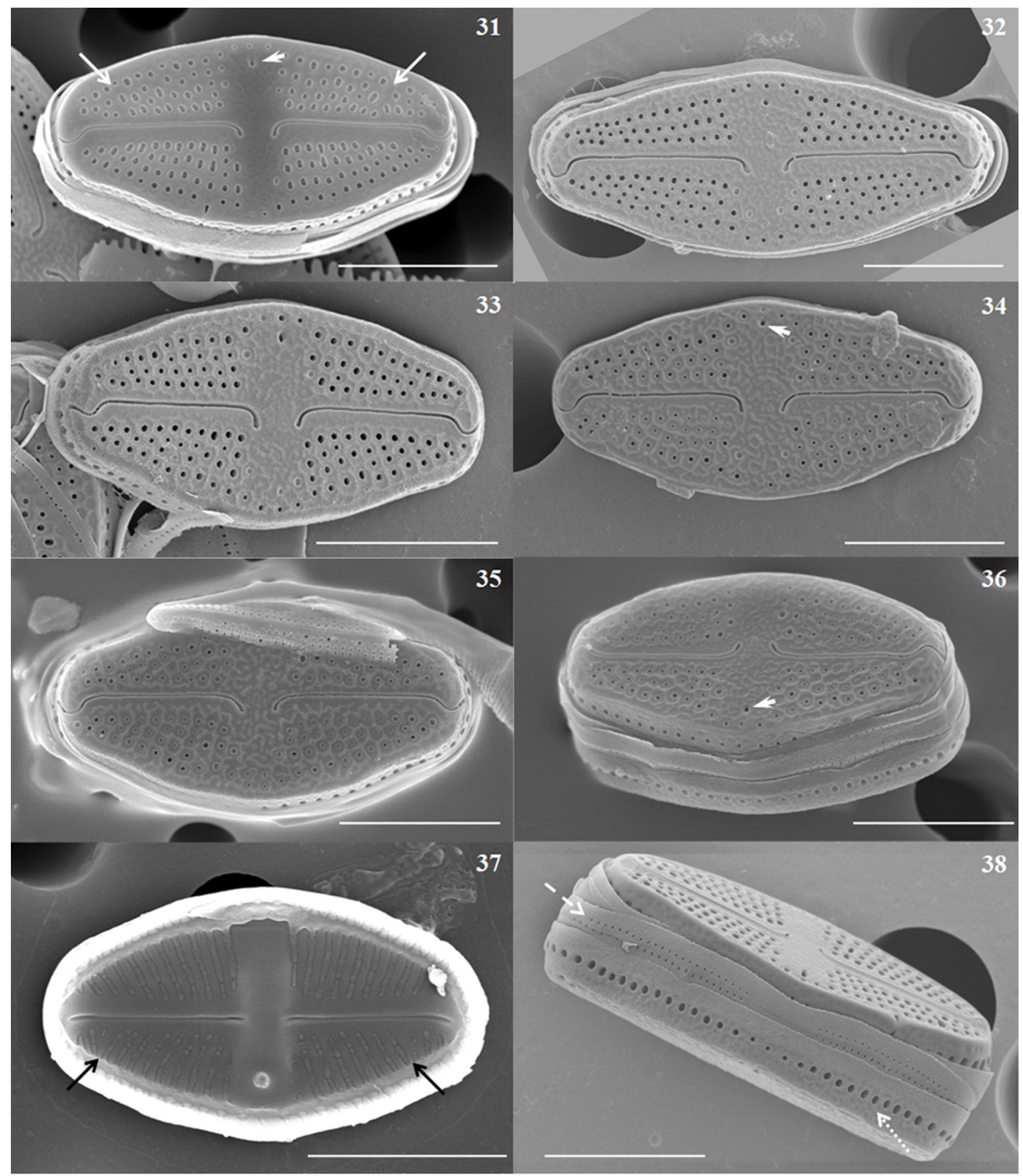

Figs 31-38. Luticola rojkoviensis sp. nov. SEM external valve view of small valves: (31-36) different intensity of depressions formed on the whole valve face, (31-32) minimal, (33) moderate, (34-36) markedly. SEM internal view of small valve: (37) note distal raphe ends with rather inconspicuous helictoglossae, $(31,37)$ arrows point to Voigt discontinuity, $(31,34,36)$ short full arrows to stigma. SEM external girdle view of small frustule: (38) note single row of pores on the valve mantle (dotted arrow) and two rows of round poroids on the girdle band (dashed arrow). Scale bar $5 \mu \mathrm{m}$.

of total asymmetry in valve outline into components of directional asymmetry (DA) and fluctuating asymmetry (FA). Natural populations (KuLICHOvé et al. 2019) and genetically uniform clonal populations (WOODARD \& Neustupa 2016) examined in this way have shown that FA within a species was mostly not correlated with the valve size, and that a less complex shape in small cells does not mean less variability. Consideration was also given to the possibility that the entire valve outline of
Luticola species could be systematically asymmetric in relation to the pattern of its central area, if the DA of the central area is distinct (WoOdARD \& NeUSTUPa 2016).

The frustules of $L$. rojkoviensis sp. nov. are weakly asymmetric to the apical axis and the asymmetry is recognizable in every cell size. The asymmetry of Luticola cells is relatively common, it has been observed in several taxa, e.g. L. beyensii Van de Vijver, Ledeganck et Lebouvier, L. ectorii, L. acidoclinata, L. aequatorialis 


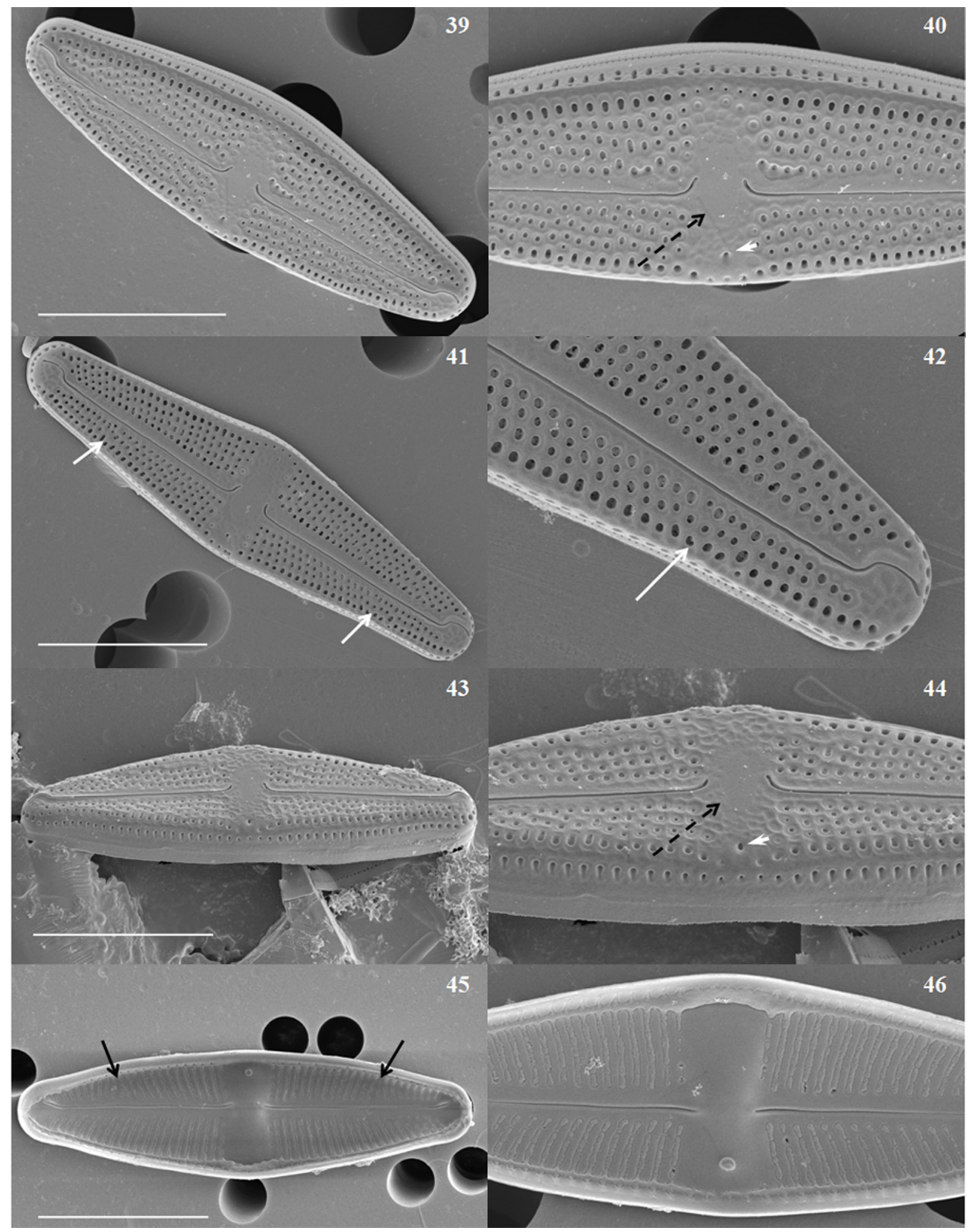

Figs 39-46. Luticola rojkoviensis sp. nov., SEM external view of large valves: $(39,41,43)$ whole valves, $(40,44)$ detailed view of the external mid-valve with proximal raphe endings unilaterally deflected to opposite side to the stigma, note that the central area around the central nodule remains smooth (dashed arrows), short arrows points to stigma; (42) detailed view of valve with Voigt discontinuity (arrow) and bayonet-shaped distal raphe endings, weakly elevated. SEM internal view of large valve: (45) the whole valve, the arrows point to Voigt discontinuity, (46) detailed view of the internal mid-valve, the internal opening of the stigma covered with a tongue-like structure, the central nodule is strongly thickened. Scale bar $10 \mu \mathrm{m}$.

(Heiden) Lange-Bertalot et Ohtsuka, L. intermedia (Hust.) Levkov, Metzeltin et A.Pavlov (taxa from group D) or in L. hustedtii, L. kochiae Metzeltin, L. grupcei A.Pavlov (with slightly asymmetric dorsiventral valves, PAVLOV et al. 2009), L. africana Levkov, Metzeltin et A.Pavlov (taxa from other groups, e.g. N, J, G). Larger valves of L. rojkoviensis sp. nov. resemble those of L. fuhrmanii Metzeltin et Levkov whose original description states that 
the valves are asymmetric - dorsiventral (cf. LEVKOV et al. 2013). Naviculoid and slightly dorsiventral valves are one of the characters of genera of the order Cymbellales, e.g. Encyonopsis Krammer and Encyonema Kützing (some representatives of both genera were previously placed in the genus Cymbella C.Agardh) which are classified as ,asymmetric biraphid diatoms“. The question arises to what extent dorsiventral frustules (a type of asymmetry) can be considered a feature of the genus Luticola which is currently classified in the group of „symmetric biraphid diatoms“.

In valves of $L$. rojkoviensis sp. nov. we have recorded another asymmetric structure - two interruptions of striae on the secondary side of valve, approximately in the first fifth of the valve size from each end. In the monograph of Luticola, LM- and SEM- micrographs of L. beyensii (cf. P1. 23: 29-35), L. fuhrmanni (cf. P1. 23: 13, 16, 18 ) or L. rhombica (Zimmerm.) Levkov, Metzeltin et A.Pavlov (cf. Pl. 23: 40, 41) show a similar structure on some valves. Such interruptions known as Voigt discontinuity are explained as faults in stria pattern, where the arms fuse (Round et al. 1990) or in other words, it marks the point of fusion of the sternum during ontogeny (https://diatoms.org/glossary/voigt_discontinuity). In our studied material, both small and large valves showed this structure (arrows in LM: Figs 17, 28; SEM: Figs $31,37,41,42,45)$. The asymmetry of proximal raphe fissures visible in the SEM micrographes of $L$. rojkoviensis sp. nov. is most probably due to asymmetry of the central area.

\section{Valve undulation}

Small frustules of L. rojkoviensis sp. nov. have weakly tri-undulate margins well visible in LM (Figs 9, 11). Scrutiny of the original LM micrographs of L. ectorii revealed similarities, mainly with populations of $L$. ectorii from SW China (LEVKov et al. 2013). Unfortunately, its original description does not mention the valve undulation.

The valve undulation is clearly recognizable in L. rhombica. The original drawing of rhombic-lanceolate valve expanded in the middle with five-undulate margins (ZIMMERMAN 1919) does not correspond with the undulation of $L$. rojkoviensis sp. nov. Valves of $L$. rhombica resemble much more those of $L$. ectorii with respect to the valve outline and the more pronounced valve undulation, when comparing LM micrographs of both taxa in the monograph (LEVKOV et al. 2013). Obviously, the use of attributes expressing intensity, in this case "weakly", may differ from author to author and therefore needs to be re-evaluated.

Another taxon with weakly tri-undulate valve margins is L. cholnokyi Levkov, Metzeltin et A. Pavlov, but can be differentiated from L. rojkoviensis sp. nov. or L. ectorii by the valve outline and the shape of the valve apices.

\section{Valve surface}

L. rojkoviensis sp. nov. is characterised by an uneven valve surface due to many depressions of varying intensity: from minimal (or perhaps absent, Figs 31-32) to well developed (Figs 33-36, 39-44) but well visible only in SEM (see diagnosis above). If present, they cover the whole external valve face, but not systematically. In small frustules, the central area and the area around the distal raphe endings are slightly pronounced (wrinkled) compared to the much more uneven area of striae (Fig. 36). In large frustules with uneven valve face, the central area around the central nodule remains smooth (Figs 39, 41, 43, in Figs 40, 44 dashed arrows).

In the monograph of Luticola (LEVKov et al. 2013) several taxa were documented with similar ultrastructure. Descriptions of uneven surface, if any, differ and no attention was paid to the area in which this ultrastructure is formed. Although the entire surface of the valve is uneven, according to the SEM micrographs presented in the book, all comments were focused mostly to the central area of the valve. We can summarize these descriptions as follows: ,small irregular depressions present throughout the central area“ (L. hustedtii); ,the depressions are irregular in the central area“, eventually: ,areolae foramina located in irregular depressions producing uneven appearance of valve face and giving impression of irregular longitudinal rows" (L. ectorii); „recessed external foramina of areloae can cause slightly uneven appearance of valve face“ (L. pseudoimbricata Levkov, Metzeltin et A. Pavlov, or L. cholnokyi) or ,this is an ornamentation with depressions that do not penetrate the valve" (L. acidoclinata). Finally, such an ultrastructure, well documented with SEM, remained without any comments in the original text of L. cholnokyi or in the text of L. intermedia.

In our studied material, the external foramina of areolae are surrounded by higher elevations, and the grouping of them gives a honeycomb-like impression in SEM (Figs 33-36, 43, 44). The elevations around the areolae appear to be the highest on one side, near the valve edge, and form structure resembling peaks (Figs 36, 44). Peaks can also be joined, mostly transapically and it is possible that these structures also give the impression of irregular longitudinal rows in LM. Internally, transapical grooves (Figs 37, 45, 46) could also contribute to the appearance of striae in the LM as by L. mutica (Kütz.) D.G.Mann (PHIPPs et al. 1983).

As cells without any discernible depressions on the valve face were observed in our studied populations, we assume that the presence or absence of this feature may depend on the stage of development during the cell cycle.

In addition, SEM micrographes show that the valve face is not in one plane. The axial area is lowered and the area around distal raphe endings elevated (e.g. Figs 36, 41-44), just slightly, therefore the valve face is concave (minimally, mostly visible in cells with well developed depressions, Figs 36, 38). A somewhat similar appearance of valves has been documented in type material of L. grupcei and L. goeppertiana (Bleisch) D.G.Mann (cf. Figs 50, 51, 59 in PAVLOV et al. 2009). The slope of 
the sample in the SEM should be taken into account, the more tilted the samples, the more pronounced the valve structures may appear.

\section{Valve size}

Our analyses of material collected in Rojkov showed a hiatus in the cell size of $L$. rojkoviensis sp. nov.: small cells $11.7-15.2 \mu \mathrm{m}$ length, $6-6.7 \mu \mathrm{m}$ width and large cells 25-32 $\mu \mathrm{m}$ and 7-9 $\mu \mathrm{m}$ width. We probably did not catch individuals in the whole life cycle, but it is also possible that only specimens of these two size ranges were present in the locality. Small cells of L. rojkoviensis sp. nov. have a comparable valve outline and size as L. nana Levkov, Metzeltin et A. Pavlov. However, we cannot compare the large individuals of our studied Luticola because large cells of L. nana are absent - there is a certain possibility that documented small cells represent the smallest cells which could be within sexual size range or at the end of their life cycle, and hence the largest cells have not been recorded.

Another confusion associated with size reduction may occur when the smallest cells of different taxa have similar appearance (in LM or in SEM), e.g. the rhombiclanceolate valves of $L$. subrostrata Metzeltin, R.L.Lowe et Levkov and L. nana; or small frustule of L. rhombica (cf. LeVKov et al. 2013). Unfortunately, some of these species lack important data on their ultrastructure (SEM analyses are not available), which makes it impossible to compare related taxa.

\section{Position of stigma and the shape of central area}

The position of the stigma in the central area of $L$. rojkoviensis sp. nov. is asymmetric, close to the margin of the secondary valve side, as in many other taxa, e.g. L. hustedtii Levkov, Metzeltin et A. Pavlov, L. ectorii, L. rhombica, L. acidoclinata, or L. pseudoimbricata.

The central area of the studied Luticola is wide, weakly asymmetrical, wedge-shaped, on both sides bordered by $3-5$ isolated round areolae. Due to the different evaluation of the shape by the authors, the interpretation of the shape of the central area is debatable. In some cases, the shape of the central area is different even for the same taxon: e.g. central area in L. grupcei is a panduriform stauros not reaching the valve margins (PAVLOV et al. 2009), and later, central area is bow-tie shaped (LEVKov et al. 2013). The variability of the central area appears to be large in some taxa as it is evident from the descriptions in L. beyensii, L. acidoclinata, or L. rhombica: wide, rectangular to slightly asymmetrical or wedge shaped to bow-tie shaped (LEVKOV et al. 2013). The original description of Navicula mutica var. stigma R.M.Patrick, currently regarded as a synonym of L. stigma (R.M.Patrick) J.R.Johansen, states that the central area is transverse (BISHOP 2015). The taxon is included in the monograph of Luticola and the central area is described more precisely than a wide, weakly asymmetric, wedge-shaped to bow-tie shaped (LEVKOV et al. 2013). This is an example of different individual approaches in assessing morphological structures of frustules including the shape of central area. This applies to the original descriptions as well as their additions from other authors.

\section{Distribution}

Until now, L. rojkoviensis sp. nov. is known only from the type locality. We recorded small populations close to the base of geoglossoid fungi (Geoglossaceae) growing on soil in grassland. The fruiting body of the fungus (above ground part) together with its lowest part (a mesh of hyphae resembling a bird's nest), hidden under higher halms of grass, mosses and flowers, represent an optimal microclimate suitable for the development of diatoms and other soil algae, and the association with fungi could be seen as an example of commensalism. The hirsute ascocarp with probably longer lasting water availability is favourable to Luticola cells as well as to filamentous cyanobacteria of orders Oscillatoriales and Synechococcales that are able to cover the whole surface of geoglossoid fungi. Both Luticola cells and cyanobacteria filaments can actively move to more favourable environments to minimize habitat stress such as temperature fluctuations and limited moisture availability (for different moisture tolerances of diatoms see Souffreau et al. 2013). In our samples only coccal green algae were present, less diatoms such as Hantzschia amphioxys, Luticola sp., Mayamaea fossalis, Humidophila contenta or Nitzschia palea. Other terrestrial diatoms were rarely found in samples with larger valves of new Luticola: Mayamaea atomus, Pinnularia appendiculata, P. lundii, Encyonopsis falaisensis. This diatom community can be considered as characteristic of a given type of rock environment (formed by grey marly limestones and marly shales which are covered by loamy-stony talus sediments), none of them indicates an acidophilic environment.

An exceptional case of coexistence of diatoms and lichenized fungi was first reported from a tropical rain forest where diatoms have directly benefited from the environment created mainly by the mycobiont (LAKATOS et al. 2004). All thalli were inhabited by various diatoms, incl. Luticola species (two of them were dominant: $L$. muticoides and Luticola $\mathrm{sp}_{1}$, the other only rare: $L$. cf. dismutica, L. acidoclinata and Luticola $\mathrm{sp}_{2}$ ). Comparison of our populations with those of $L$. acidoclinata would be interesting also because of the possible relationship between the occurrence of some fungi and diatoms. Unfortunately, cells of tropical L. acidoclinata have been recorded as rare, and only SEM micrographs containing two other dominant diatoms are present in the study.

Many Luticola species are known from subaerial habitats, mosses, soils, rocks in Europe (PoulíčKová \& HAŠLER 2007; PAVLOV et al. 2009; LeVKOV et al. 2013, 2017; NogA et al. 2017), it is therefore very likely that $L$. rojkoviensis sp. nov. will be accompanied also by other Luticola species in different parts of grassland at Rojkov.

Taxa that are morphologically similar to L. rojkoviensis sp. nov. (see Table S1) were originally described not 
only from similar environments, but also from extreme habitats including cold regions of Antarctica: L. beyensii, or from sub/tropical regions in Africa: $L$. hustedtii and $L$. fuhrmannii (Tanzania, Usambara Mountains, not specified), or from South America: L. ectorii (Brazil, mud of lake), L. rhombica (Brazil, not specified).

One of the representatives of the genus Luticola, originally described from an usual environment, is the European species L. acidoclinata. Its populations were originally described from mud of lake Weinfelder Maar in Germany, from oligotrophic, electrolyte-poor, circumneutral to slightly acidic water. According to LANGEBERTALOT, the autecology has been confirmed by other findings in oligo-dystrophic lakes in Scandinavia, and this habitat was considered to be an important criterium for the delimitation of similar taxa, e.g. populations of L. saxophila, which has been found in many subaerial habitats (Lange-Bertalot \& Metzeltin 1996). Since then, populations identified as L. acidoclinata sensu LEVKOV et al. (2013) have frequently been recorded in many other biotopes. One of the recent studies of the diatom flora of halomorphic soils identified populations of $L$. acidoclinata that were well adapted even to this extreme habitat (LeVkov et al. 2017). Afterwards, the dominant occurrence of L. acidoclinata on poplar bark representing the aerophytic environment was recorded by RYBAK et al. (2018). Based on several other observations, the authors consider that L. acidoclinata is a rare species in the waters, and its optimal occurrence is in aerophytic environments, especially among mosses. Until now, all these determinations were based on the ultrastructure of populations sensu LEVKOV et al. (2013), but not of the type material. LANGE-BERTALOT's opinion on the strict ecological requirements of this taxon, whose species name also indicates the type of habitat, therefore remains valid (LANGE-Bertalot \& Metzeltin 1996). The knowledge of phenotypic expressions of variable environmental conditions is still limited, so we assume that the number of taxa included in the ,L. acidoclinata - complex" or in other complexes will be the subject of further taxonomic work.

\section{ACKNOWLEDGEMENTS}

The authors would like to thank Dr. Petr Marvan for his important taxonomic remarks, Dr. Viktor Kučera for the mycological material, Dr. Hans Sluiman for English corrections and the reviewers for their helpful comments. Our study was supported by the Slovak Research and Development Agency APVV-15-0210.

\section{REFERENCES}

ANDREeva, S.A.; Kulikovskiy, M.S.; Maltsev, Y.I.; PodunAI, Y.A. \& GuSEv, E. (2016): Molecular genetic investigation of diatom genera Diadesmis and Humidophila (Bacillariophyceae). - Bot. Zhurn. 101: 621-628.

Ashworth, M.P.; LobBan, C.S.; Witkowski, A.; Theriot, E.C.; SABIR, M.J.; BAEShen, M.N.; HAJARAH, N.H.; BAESHEN, N.A.; SABIR, J.S. \& JANSEN, R.K. (2017): Molecular and morphological investigations of the stauros-bearing, raphid pennate diatoms (Bacillariophyceae): Craspedostauros EJ Cox, and Staurotropis TBB Paddock, and their relationship to the rest of the Mastogloiales. - Protist 168: 48-70.

Bąk, M.; KryK, A.; Peszek, L.; Kociolek, J.P.; Bemiasa, J. \& Bemanaja, E. (2019): New and interesting Luticola species (Bacillariophyta) from the mangroves of Nosy Be Island, NW Madagascar. - Oceanological and Hydrobiological Studies 48: 13-22.

Bishop, I. (2015): Luticola stigma. - In Diatoms of North America. https://diatoms.org/species/luticola_stigma

Chattová, B.; Lebouvier, M.; De HaAn, M. \& Van de Vijver; B. (2017): The genus Luticola (Bacillariophyta) on Ile Amsterdam and Ile Saint-Paul (Southern Indian Ocean) with the description of two new species. - European Journal of Taxonomy 387: 1-17.

Glushchenko, A.M. \& KulikovskiY, M.S. (2015): Species of the genus Luticola in waterbodies of Laos and Vietnam. - Bot. Zhurn. 100: 799-804. (In Russian)

Glushchenko, A.M.; KulikovskiY, M.S. \& Kociolek, J.P. (2017): New and interesting species from the genus Luticola (Bacillariophyceae) in waterbodies of Southeastern Asia. - Nowa Hedwigia 146: 157-173.

GuirY, M.D. \& GuIRY, G.M. (2020): AlgaeBase. - World-wide electronic publication, National University of Ireland, Galway. http://www.algaebase.org

HindÁKová, A. \& HindÁK, F. (2015): Cyanobacteria and algae of mineral springs of the fen Močiar at Stankovany, Central Slovakia. - Bull. Slov. Bot. Spoločn. 37: 161-167.

Kociolek, J.P.; Kopalová, K.; Hamsher, S.E.; Kohler; T.J., VAn De Vijver; B.; Convey, P. \& McKnight, D.M. (2017): Freshwater diatom biogeography and the genus Luticola: an extreme case of endemism in Antarctica. - Polar Biol. 40: 1185-1196.

Kohler, T.J.; Kopalová, K.; VAN De ViJver, B. \& KocioleK, J.P. (2015): The genus Luticola D.G. Mann (Bacillariophyta) from the McMurdo Sound Region, Antarctica, with the description of four new species. - Phytotaxa 208: 103-134.

Kopalová, K.; Elster, J.; Nedbalová, L. \& VAn de Vijver, B. (2009): Three new terrestrial diatom species from seepage areas on James Ross Island (Antarctic Pennisula Region). - Diatom Research 24: 113-122.

Kopalová, K.; NedBalová, L.; DE HaAn, M. \& VAN DE ViJVER, B. (2011): Description of five new species of the diatom genus Luticola (Bacillariopyta, Diadesmidaceae) found in lakes of James Ross Island (Maritime Antarctic Region). - Phytotaxa 27: 44-60.

Kulichová, J.; Neustupa, J.; Vrbová, K.; Levkov, Z. \& KopalovÁ, K. (2019): Asymmetry in Luticola species. - Diatom Research 34: 67-74.

Lakatos, M.; Lange-Bertalot, H. \& Büdel, B. (2004): Diatoms living inside the thallus of the green algal lichen Coenogonium linkii in neotropical lowland rain forests. - J.Phycol. 40: 70-73.

Lange-Bertalot, H. \& Metzeltin, D. (1996): Indicators of oligotrophy. 800 taxa representative of three ecologically distinct lake types, carbonate buffered-oligodystrophic-weakly buffered soft water. - Iconographia Diatomologica 2: 1-390.

Levkov, Z.; Metzeltin, D. \& Pavlov, A. (2013): Luticola and Luticolopsis. - Diatoms of Europe. Diatoms of the European inland waters and comparable habitats. 7: $1-698$

Levkov, Z.; Tofilovska, S.; Wetzel, C.E.; Miti'C - Kopanja, 
D. \& ECTOR, L. (2017): Diversity of Luticola D.G. Mann (Bacillariophyceae) species on halomorphic soils from Gladno Pole, Central Macedonia. - Nova Hedwigia, Beihefte 146: 175-196.

Malík, P.; Kováčová, E.; Bottlik, F.; Kordík, J. \& Polák, M. (2006): Základná hydrogeologická a hydrogeochemická mapa západnej časti Vel'kej Fatry v mierke 1:50 000. Archív odboru Geofondu ŠGÚDŠ Bratislava.

Nakov, T.; Beaulieu, J. M. \& Alverson, A. J. (2018): Accelerated diversification is related to life history and locomotion in a hyperdiverse lineage of microbial eukaryotes (Diatoms, Bacillariophyta). - New Phytologist 219: 462-473.

Noga, T.; StaneK-Tarkowska, J.; Kochman-Kedziora, N.; Rybak, M.; Peszek, L. \& Poradowska, A. (2017): Luticola frequentissima Levkov, Metzeltin \& Pavlov -morphological and ecological characteristics of a population from Southern Poland. - Oceanological and Hydrobiological Studies 46: 237-243.

Ogura, A.; Akizuki, Y.; Imoda, H.; Mineta, K.; Gojobori, T. \& NAGAI, S. (2018): Comparative genome and transcriptome analysis of diatom, Skeletonema costatum, reveals evolution of genes for harmful algal bloom. - BMC Genomics 19: 765.

Pavlov, A.; Nakov, T.; Levkov, Z.; Furey, P.; Lowe, R. \& Ector, L. (2009): Luticola grupcei (Bacillariophyceae) - a new freshwater diatom from Mountain Baba (Macedonia) and Great Smoky Mountains National Park (U.S.A.): comparison with the type material of $L$. goeppertiana (Bleisch) D.G.Mann. - Nova Hedwigia 89: 147-164.

PhIPPS, D.W. Jr. \& Rosowski, J.R. (1983): The morphology and integration of valves and bands in Navicula mutica var. mutica (Bacillariophyceae). - J. Phycol. 19: 320-323.

Pinseel, E.; Hejduková, E.; Vanormelingen, P.; Kopalová, K.; Vyverman, W. \& DE ViJVer, B. V. (2016): Pinnularia catenaborealis sp. nov. (Bacillariophyceae), a unique chain-forming diatom species from James Ross Island and Vega Island (Maritime Antarctica). - Phycologia 56: 94-107.

Polák, M.; BujnovskÝ, A.; Kohút, M.; Filo, I.; Pristaš, J.; Havrila, M.; Vozár, J.; Mello, J.; RaKús, M.; BuČEK, S. \& LeXA, J. (1997): Geologická mapa Vel'kej Fatry $1: 50$ 000. Regionálne geologické mapy Slovenska. - Vydavatel'stvo ŠGÚDŠ Bratislava.

PoulíčKové, A. \& HašLER, P. (2007): Aerophytic diatoms from caves in central Moravia (Czech Republic). - Preslia 79: 185-204.

Round, F.E.; Crawford, R.M. \& Mann, D.G. (1990): The diatoms. Biology and morphology of the genera. -747 pp., Cambridge University Press, Cambridge.

RybaK, M.; Noga, T. \& Zubel, R. (2018): The aerophytic diatom assemblages developed on mosses covering the bark of Populus alba L. - Journal of Ecological Engineering 19: 113-123.
Souffreau, C.; VAnormelingen, P.; VAn de VijVer, B.; IsheVA, T.; Verleyen, E; Sabbe, K. \& Vyverman, W. (2013): Molecular evidence for distinct Antarctic lineages in the cosmopolitan terrestrial diatoms Pinnularia borealis and Hantzschia amphioxys. - Protist 164: 101-115.

Spaulding, S. \& Edlund, M. (2008): Luticola. - In Diatoms of North America. https://diatoms.org/genera/ luticola

Straube, A.; Tremarin, P.I. \& Ludwig, T.A.V. (2017): Species of Luticola D.G.Mann (Bacillariophyceae) in the Atlantic Forest rivers from southern Brazil. - Diatom Research 32: 417-437.

TOPERCER, J. \& Bernátoví, D. (2013): Ničivé vplyvy a hrozby pre vegetáciu Prírodnej rezervácie Rojkovské rašelinisko, Prírodnej rezervácie Močiar a severných strání Kopy. - Naturae Tutela 17: 5-14.

VAn de Vijver, B.; Van Dam, H. \& Beyens, L. (2006): Luticola higleri sp. nov., a new diatom species from King George Island (South Shetland Islands, Antarctica). - Nova Hedwigia 82: 69-79.

Wetzel, C.E.; VAN DE ViJVER, B. \& Ector, L. (2010): Luticola deniseae sp. nov. A new epizoic diatom from the Rio Negro (Amazon hydrographic basin). - Vie et Milieu 60: $177-184$.

WoODARD, K. \& NeUSTUPA, J. (2016): Morphometric asymmetry of frustule outlines in the pennate diatom Luticola poulickovae (Bacillariophyceae). - Symmetry 8: 150.

Zidarova, R.; Levkov, Z. \& VAN De ViJVer; B. (2014): Four new Luticola taxa (Bacillariophyta) from Maritime Antarctica. - Phytotaxa 170: 155-168.

Zimmerman, S.J.C. (1919): Quelques Diatomées nouvelles ou curieuses. - Broteria (Ciencias Naturais), Serie Botanica 17: 97-100.

https://diatoms.org/glossary/voigt_discontinuity

Supplementary material

The following supplementary material is available for this article:

Table S1. Main morphological features of Luticola rojkoviensis sp. nov. and similar species, with their habitat preferences and geographic distribution according to their original descriptions. Information that was not available is marked by a dash.

This material is available as part of the online article (http:// fottea.czechphycology.cz/contents)

(C) Czech Phycological Society (2021)

Received June 6, 2020

Accepted September 24, 2020 